\author{
ЮГОЗАПАДЕН УНИВЕРСИТЕТ \\ „НЕОФИТ РИЛСКИ“ \\ ФИЛОЛОГИЧЕСКИ ФАКУЛТЕТ
}

\title{
ЕЗИКОВ СВЯТ
}

\section{ORBIS LINGUARUM}

\author{
Том 19
}

Кн. 3 
НАУЧНОТО СП. „ЕЗИКОВ СВЯТ“ СЕ ИЗДАВА С ПОДКРЕПАТА НА ФОНД „НАУЧНИ ИЗСЛЕДВАНИЯ“. ТО Е ИНДЕКСИРАНО В SCOPUS, ERIH PLUS, CENTRAL AND EASTERN EUROPEAN ONLINE LIBRARY (CEEOL), ULRICH'S PERIODICALS, РИНЦ (РОССИЙСКИЙ ИНДЕКС НАУЧНОГО ЦИТИРОВАНИЯ), CROSSREF, CNKI (CHINA)

DOI НА СПИСАНИЕТО Е10.37708/EZS.SWU

Езиков свят

Том 19

Кн. 3

Университетско издателство

„Неофит Рилски“, Благоевград

(C) Художник на корицата

Проф. Георги Драчев

Проф. Емил Куков

Банкови сметки: ОБЩИНСКА БАНКА АД

IBAN: BG62SOMB91303160613000

BIC: SOMBBGSF 


\author{
ЮГОЗАПАДЕН УНИВЕРСИТЕТ \\ „НЕОФИТ РИЛСКИ“ \\ ФИЛОЛОГИЧЕСКИ ФАКУЛТЕТ
}

\title{
ЕЗИКОВ СВЯТ
}

\section{Tом 19}

Кн. 3

Благоевград

2021 г. 
Списание „Езиков свят“ се издава от Филологическия факултет на ЮЗУ „Неофит Рилски“, Благоевград. Списанието публикува материали, посветени на езиковото обучение, сьпоставителни изследвания, лингвокултурология, странознание и литературоведски изследвания. Статиите, рецензиите и отзивите, подготвени за публикуване в сп. Orbis Linguarum (Езиков свят), трябва да са в MSWord със следните параметри: максимална дължина: 15 стандартни страници; полета: (отгоре, отдолу, отдясно, отляво) 2,54 см; подравняване: Justify, с отстьп 1.25 см; шрифт: Times New Roman, размер на шрифта: 11 pt, редово пространство: Single.

Всеки ръкопис трябва да съдържа: 1. Заглавие: размер на шрифта: 12 pt, All Caps, Bold. 2. Име и фамилия на автора (авторите): размер на шрифта: 11 pt; All Caps, за фамилията (фамилиите), Ital., институт/университет, държава, e-mail. 3. Заглавие на статията на английски език: подравняване: Align Left, All Caps, размер на шрифта: 10 pt, Bold. 4. Име и фамилия на автора (авторите) на английски език: подравняване: Align Left, All Caps, paзмер на шрифта: 10 pt, Ital. 5. Резюме на английски език: Justify, размер на шрифта: 9 pt, максимална дължина 250 думи. 6. Ключови думи на английски език: не повече от 7 на брой, размер на шрифта: 10 pt. 7. Бележка под линия: Times New Roman, Single, Justify, размер на шрифта: 10 pt. 8. Цитати в текста: a) (Panova, 1980, p. 29); б) Panova (1980) states that criticism is of extreme importance in decision making. 9. Библиография: Times New Roman, Justify, размер на шрифта: 10 pt, напр.:

Ангелов, Б. (1971)

Chomsky, N. (1974)

Rolin, D.(2002a)

Rolin, D.(2002b)

Сказание за железния кръст. // Старобългарска литература, № 1, с. 136 - 155.

(Angelov, B. The Legend of the Iron Cross. //Starobalgarska literatura, № 1, s. 136 -155$.

Bemerkungen zum Anarchismus. - In: Aus Staatsraison. Frankfurt, S.104-121.

Dulle Griet. Bruxelles, 166 p.

Plaisirs. Paris, 207 p.

Материали, които не отговарят на изискванията, не се разглеждат и не се рецензират. Авторите носят отговорност за оригиналността на приетите за публикуване текстове.

\section{Редакционен съвет:}

Проф. Дейвид Инграм (Arizona State University, USA), проф. Сергей Бирюков (Martin-LutherUniversität Halle-Wittenberg, Germany),проф. Анна Хамлинг (Culture and Media Studies, University of New Brunswick Fredericton, Canada), проф. Мотоки Номати (Hokkaido University, Japan), проф. Иван Касабов (New Bulgarian Univerity, Bulgaria), проф. Василка Радева (Sofia University, Bulgaria), npoф. Григорий Венедиктов (Russian Academy of Science, Russia), проф. Елена Узеньова (Russian Academy of Science, Russia), nроф. Лиу Джъбай (Beijing Foreign Studies University, China), проф. Димитър Бело (University of Tirana, Albania), д-p Ваня Станишич (University of Belgrade, $\underline{\text { Serbia) }}$

\section{Редакционна колегия:}

проф. д.ф.н. Магдалена Костова-Панайотова (panayotova@swu.bg), проф. д-р Лилия Илиева (lilia.ilieva@swu.bg), проф. д-р Стилиян Стоянов (stilyan@swu.bg) и проф. д. ф. н Цветан Ракьовски (crakiovsky@swu.bg)

Дежурни редактори: дои. д-р Дафина Костадинова, доч. д-р Бойка Илиева, дои. д-р Биляна Тодорова, гл. ас. д-р Мария Анастасова, ас. д-р Наделина Ивова

Главен редактор: проф. д.ф.н. Магдалена Костова-Панайотова

Филологически факултет

Тел.: +35973 $88-55-01 ; 8889-123$;

Факс: +35973 889 - 123;

E-mail: ezikovsvyat@ abv.bg; magipkp@mail.bg.

ISSN 1312 - 0484 (Print)

ISSN 2603-4026 (Online) 
ТЕОДОРА Г. ИЛИЕВА. ФРАЗЕОЛОГИЧНИ ИЗРАЗИ С ОПОРНА ДУМА 'КРЬСТ' В 7 БЪЛГАРСКИ И В РУСКИ ЕЗИК

MARIANA OLENIAK. OLD ENGLISH SWA SIMILES: STRUCTURE OVERVIEW

ТИЈАНА БАЛЕК. РЕЛАТИВНЕ КАРИТИВНЕ КОНСТРУКЦИЈЕ СА ВЕЗНИЧКО- 30 ПРЕДЛОШКИМ СПОЈЕМ ИЛИ БЕЗ У СРПСКОМ ЈЕЗИКУ (УЗ ОСВРТ НА СИТУАЦИЈУ У РУСКОМ ЈЕЗИКУ)

ЕУННАРЕ ЧО. ИЗРАЗЯВАНЕ НА ПОДБУДИТЕЛНОСТ В КОРЕЙСКИЯ И БЪЛГАРСКИЯ 42 ЕЗИК

МАРИЯ БАГАШЕВА. ПОГОВОРКИ И ФРАЗЕОЛОГИЗМИ В РОМАНА „ПОД ИГОТО“ НА 52 ИВАН ВАЗОВ И ПРЕДАВАНЕТО ИМ НА АНГЛИЙСКИ И РУСКИ ЕЗИК

SHPËTIM ELEZI, VIOLETA PLLANA ELEZI. THE USE OF STANDARD ALBANIAN LANGUAGE 59 BY PRIMARY SCHOOL TEACHERS

НАДЕЛИНА ИВОВА. НАЗВАНИЯТА ЗА ЧЕРЕН И БЯЛ ЦВЯТ В БЪЛГАРСКАТА, ПОЛСКАТА 71 И ЛИТОВСКАТА ФРАЗЕОЛОГИЯ

NATALIA SIUDZIŃSKA. KOMPETENCJE SŁOWOTWÓRCZE POLSKICH $\quad$ DZIECI 83 DWUJĘZYCZNYCH MIESZKAJĄCYCH W IRLANDII (NA PRZYKŁADZIE NAZW OSOBOWYCH ŻEŃSKICH)

НАТАЛИЯ СОТИРОВА-МИЛЧЕВА. АБСТРАКТНИ ДЕВЕРБАЛНИ ФОРМАЦИИ С ОСНОВИ ОТ ГРЫЦКИ ПРОИЗХОД

VIERA LAGEROVA. ČÍTANIE AKO PROSTRIEDOK AKVITIZÁCIE ŽIAKOV 97

ЕЛЕНА КРЕЙЧОВА. ТРИДЕСЕТГОДИШЕН ЮБИЛЕЙ НА СПИСАНИЕ „ОПЕРА СЛАВИКА“ 105 (ЧЕХИЯ) - НАУЧНА КОМУНИКАЦИЯ, БЪДЕЩЕ И РАЗВИТИЕ

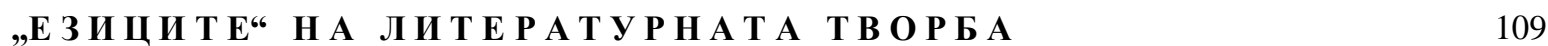
МАГДАЛЕНА КОСТОВА-ПАНАЙОТОВА. „ПЕРИФЕРИЯТА - МЯСТОТО, КЬДЕТО СЕ 109 РАЗКРИВА БЪДЕЩЕТО“ (МЕЖДУ ИЗТОКА И ЗАПАДА - ГРАНИЦИ И ИДЕНТИЧНОСТИ)

АМЕЛИЯ ЛИЧЕВА. ПОСТФЕМИНИЗЬМ

NESHEN ISAEVA-GYUNESH. CIRCULATIONS OF AFFECTS: AFFECTIVE MEMORIES: THE 125 SOLDIER IN SARAH KANE'S BLASTED

РОМАН ХАДЖИКОСЕВ. БАЛКАНСКАТА КОМЕДИЯ НА БОРЮ ЗЕВЗЕКА - ИЗМЕРЕНИЯ НА 133 СМЕШНОТО

БОРИС МАНОВ. ВИСШЕТО ХУМАНИТАРНО И СОЦИАЛНО-НАУЧНО ОБРАЗОВАНИЕ В 138 УСЛОВИЕ НА КРИЗА - НОВ ПОДХОД ИЛИ УЛИЦА БЕЗ ИЗХОД? ОПИТ ЗА АКТУАЛНА „РЕПЛИКА“ НА ИДЕИТЕ НА Х.Р. ЯУС

Р ЕЦЕ Н ЗИИ И О Т ЗИВ И

ГЕРГАНА ПАДАРЕВА-ИЛИЕВА. ЕЗИКОВА АГРЕСИЯ И ПОЛИТИЧЕСКА КОРЕКТНОСТ. НОВОТО В РЕЧТА НА СЪВРЕМЕННОТО БЪЛГАРСКО ОБЩЕСТВО 
TIJANA BALEK. RELATIVE CARITIVE CONSTRUCTIONS WITH CONJUNCTIONPREPOSITION COMPLEX ILI BEZ IN SERBIAN (WITH AN OVERVIEW OF THE SITUATION IN RUSSIAN)

EUNNARAE CHO. EXPRESSION OF INDUCEMENT IN KOREAN AND BULGARIAN

MARIA BAGASHEVA. PROVERBS AND PHRASEOLOGICAL UNITS IN IVAN VAZOV'S NOVEL 'UNDER THE YOKE' AND THEIR REINDERING INTO ENGLISH AND RUSSIAN

SHPËTIM ELEZI, VIOLETA PLLANA ELEZI. THE USE OF STANDARD ALBANIAN LANGUAGE BY PRIMARY SCHOOL TEACHERS

NADELINA IVOVA. THE COLOR TERMS FOR BLACK AND WHITE IN BULGARIAN, POLISH AND LITHUANIAN PHRASEOLOGICAL UNITS

NATALIA SIUDZIŃSKA. WORD-FORMATION COMPETENCE IN THE CASE OF POLISH BILINGUAL CHILDREN WHO LIVE IN IRELAND (ON THE BASIS OF FEMININE GENDER WORD FORMS)

NATALIYA SOTIROVA-MILCHEVA. ABSTRACT DEVERBAL FORMATIONS WITH BASES OF GREEK ORIGIN

VIERA LAGEROVA. READING AS A MEANS OF ACTIVATING THE PUPILS

ELENA KREYTCHOVA. THIRTY-YEAR ANNIVERSARY OF OPERA SLAVICA (CZECHIA) SCIENTIFIC COMMUNICATION, FUTURE AND DEVOLOPMENT

“T H E L A N G U A G E S" OF THE L I T ERA R Y W O R K

MAGDALENA KOSTOVA-PANAYOTOVA. "THE PERIPHERY - THE PLACE THAT REVEALS THE FUTURE” (BETWEEN THE EAST AND THE WEST - BOUNDARIES AND IDENTITIES)

AMELIA LICHEVA. POSTFEMINISM

NESHEN ISAEVA-GYUNESH. CIRCULATIONS OF AFFECTS: AFFECTIVE MEMORIES: THE SOLDIER IN SARAH KANE'S "BLASTED"

ROMAN HADJIKOSEV. "BALKAN COMEDY" BY BORYU ZEVZEKA - ASPECTS OF THE COMIC

BORIS MANOV. THE HIGHEER HUMANITIES AND SOCIAL-SCIENTIFIC EDUCATION IN A CRISIS - A NEW APPROACH OR A DEAD END? AN ATTEMPT TO UPDATE A "REPLICA"OF HANS ROBERT JAUSS'S IDEAS

R E V I E W S 